\title{
Effect of feeding regime on concentration of plasma calcium, magnesium and phosphorus in heifers
}

\author{
$P$ Miettinen \\ University of Kuopio, Department of Anatomy, SF 70211 Kuopio, Finland
}

Metabolic profile tests have been used to monitor the metabolic state of dairy herds and particularly to assess the adequacy of dietary intake. Many blood components are subject to a homeostatic mechanism which militates against their use as indicators of nutritional status. Moreover, feeding regime may have an important influence on blood metabolites. Therefore, effects of two types of feeding on plasma calcium, magnesium and phosphorus were studied in heifers.

A total of 20 pregnant heifers were included in this study. The heifers were fed with mineral, and feed produced on the same farm (hay, silage, concentrate) in accordance with Finnish feeding standards. The rations were designed to contain the same amount of nutrients in terms of energy, digestible crude protein. The cows were divided according to type of feed into a hay-urea group $(H)$ and a silage group (S). The silage group was fed grass silage and, the amount of hay was limited to $1 \mathrm{~kg}$ per day. The hay-urea group was fed hay and $1 \mathrm{~kg}$ of concentrate mixture containing $2 / 3$ barley and $1 / 3$ oats. Two per cent of urea was added to the concentrate as a source of nitrogen.

Feed intake (F) was recorded and daily means of one week's follow-up period were calculated. A blood sample was taken in the 4th month of pregnancy (1) and one month before expected calving (2).

Intake of calcium and magnesium was higher in the hay-urea group ; the plasma levels (PI), however, were lower than in the silage group. No such a relationship was found for phosphorus intake.

It is concluded that the feeding regime has a major influence on plasma calcium and magnesium concentration.

\begin{tabular}{|c|c|c|c|c|c|c|}
\hline & $\begin{array}{c}\text { F1-Ca } \\
\text { (g) }\end{array}$ & $\begin{array}{c}\mathrm{F}_{1}-\mathrm{Mg} \\
(\mathrm{g})\end{array}$ & $\begin{array}{c}\text { F1-P } \\
(g)\end{array}$ & $\begin{array}{c}\mathrm{F} 2-\mathrm{Ca} \\
(\mathrm{g})\end{array}$ & $\begin{array}{c}\mathrm{F} 2-\mathrm{Mg} \\
\text { (g) }\end{array}$ & $\begin{array}{c}\text { F2-P } \\
(g)\end{array}$ \\
\hline $\mathrm{H}$ & $44.3 \pm 1.1$ & $13.5 \pm 0.6$ & $19.4 \pm 0.7$ & $42.0 \pm 0.8$ & $14.4 \pm 0.3$ & $23.3 \pm 0.5$ \\
\hline \multirow[t]{2}{*}{$S$} & $33.6 \pm 1.9$ & $10.1 \pm 0.2$ & $22.0 \pm 0.5$ & $37.6 \pm 1.7$ & $12.9 \pm 0.6$ & $21.4 \pm 1.1$ \\
\hline & $\begin{array}{c}\text { Pl-Ca } \\
\text { (mMol) }\end{array}$ & $\begin{array}{c}\mathrm{Pl}-\mathrm{Mg} \\
\text { (mMol) }\end{array}$ & $\begin{array}{c}\text { Pl-P } \\
\text { (mMol) }\end{array}$ & $\begin{array}{c}\text { Pl-Ca } \\
\text { (mMol) }\end{array}$ & $\begin{array}{l}\text { Pl-Mg } \\
\text { (mMol) }\end{array}$ & $\begin{array}{c}\text { Pl-P } \\
\text { (mMol) }\end{array}$ \\
\hline$\overline{\mathrm{H}}$ & $2.54 \pm 0.06$ & $0.98 \pm 0.02$ & $2.07 \pm 0.09$ & $2.44 \pm 0.05$ & $1.02 \pm 0.02$ & $1.85 \pm 0.04$ \\
\hline S & $2.62 \pm 0.05$ & $1.12 \pm 0.03$ & $1.95 \pm 0.05$ & $2.53 \pm 0.02$ & $1.23 \pm 0.04$ & $2.01 \pm 0.05$ \\
\hline
\end{tabular}

